\title{
ULUSLARARASI ANTLAŞMALAR HUKUKUNDA JUS COGENS KURALLAR
}

\author{
Erdem Denk \\ Ankara Üniversitesi Siyasal Bilgiler Fakültesi \\ Araşırma Gorevlisi
}

\section{Ōzet}

Bu çalışma, uluslararası antlaşmalar hukukunda jus cogens nitelikli kurallan, uluslararası hukukun yapısına ilişkin temel sorunsallardan olan "uluslararası hukukta öncelikli/üstün nitelikli kurallann varlı̆ı" konusu bağlamında ele almaktadır. Çalışmanun temel varsayımı, her toplumun olduğu gibi uluslararası toplumun da temel ve üstün nitelikli değerlere sahip olduğu ve bunun sonucu olarak uluslararası hukukun da her hukuk düzeni gibi temel değerlerini kimi kurallan yoluyla koruduğu ve koruması gerektiğidir. 1969 Viyana Antlaşmalar Hukuku Sözleşmesi'yle "jus cogens kurallar" olarak pozitif uluslararası hukuka aktarlan bu tür kurallann tanmı, kapsamı, işlevleri ve etkilerinin, söz konusu Süzleşme'nin düzenlemeleri ı̧ı̆ğında ele alındığı bu çalışmada üzerinde en fazla durulan konu, jus cogens kuralları "sıradan" uluslararası hukuk kurallanndan ayıran temel özellikler olmuştur.

Diğer yandan, jus cogens kurallann etkileri bağlamunda gündeme gelen "etkinlik" sorunu da üzerinde durulan bir diğer konudur. Bu bağlamda en dikkat çekici nokta, uluslararası toplumun temel değerlerini temsil eden jus cogens kurallara aykırı düzenlemelerin denetlenmesinin uluslararası topluma değil, sadece taraf devletlere bırakılmı olmasıdır.

\section{Jus cogens Rules in the Law of Treaties}

\section{Abstract}

This study examines the jus cogens rules in the context of the peremptory rules issue which is one of the main problematics of international law. The basic presumption of the study is, international law has (and should have) its own rules for protecting the basic values of the international community as all law orders do. The definition, extent, functions and effects of these rules, which are introduced to positive international law by the 1969 Viyana Convention on the Law of Treaties, are examined in the light of the said Convention and the main emphasis was given to the distinguishing charecteristics of $j u s$ cogens rules other than of "ordinary" ones.

On the other hand, the "effectiveness" of these rules are also studied in detail. In this context, the regulation of the said Convention, which gives the power to determine the nullity of the conflicting act solely to the parties, and not to the international community, the basic value of which is threatened, is also remarkable. 


\section{Uluslararası Antlaşmalar Hukukunda Jus Cogens Kurallar}

\section{Giriş}

Devletlerin istedikleri konuda ve içerikte sözleşme yapabilme serbestisi, uluslararası hukukun temel ilkelerinden birisidir ve devletlerin egemenliğinin bir sonucu olarak ortaya çkmaktadır. Diğer yandan, uzun zamandan beri, bu temel ilkenin kimi istisnalarınn olup olamayacağı tartışlmakta ve devletlerin uluslararası toplumun temel çıkarlanı ilgilendiren kimi konularda sözleşme yapma serbestilerinin bulunmadığı, daha doğrusu bulunmaması gerektiği ileri sürülmektedir. 1969 Viyana Antlaşmalar Hukuku Sözleşmesi'yle ${ }^{1}$ uluslararası hukuk literatürüne "jus cogens" olarak iyice yerleşen bu tip kurallar Türkçe'de "buyruk kural" ya da "amir hüküm" olarak anlmaktadır. Kendisine aykın antlaşmaları geçersiz kulan bu kuralların işlevleri, saptanması, unsurlan ve kapsamı bir yana varlığı bile -anılan Sözleşme'deki açık düzenlemeye rağmentartş̧ma konusudur. Bu çalışmanun amacı, uluslararası hukukun kendi yapısı gereği bu tür "üst/öncelikli" kuralların varlığına elverişli olup olmadığı sorusunu da sürekli akılda tutarak söz konusu kuralların varlığı, saptanması, unsurlan, kapsamı, işlevleri ve etkileri konuların gözden geçirmektir.

Yukarıda da belirtildiği gibi, jus cogens kuralların varlığının benimsenmesinin en önemli sonucu, hiç kuşkusuz, uluslararası hukukun temel ilkelerinden olan ve devlet egemenliğinin bir uzantısı olarak karşımıza çkan devletlerin sözleşme yapma serbestisinin sınırlanmasıdır. Aslında, buna göre, iç hukukta da görüldüğü gibi, hukuk sujelerinin sözleşme yapma özgürlüğü temel ilke olmakta, fakat bu özgürlük sunursiz bir nitelik yerine o toplumun temel değerleri ve toplumsal çıkar bağlamında getirilen sınurlamalarla çevrelenmektedir.

1 Sözleşme'nin metni için bkz. <http://www.un.org/law/ilc/texts/treatfra.htm> (1.11.2000). 21 Mart 1986'da Viyana'da imzalanan "Deoletlerle Uluslararası Orgütler oeya Uluslararası Orgüllerle Uluslararası Orgüller Arası Antlaşmalar Sözleşmesi"nin yine 53. maddesi, 1969 Sözleşmesi nin jus cogens kurallar konusundaki 53. maddesini aynen tekrar etmiştir. Sözleşme'nin metni için bkz. <http://www.un.org/law/ilc/texts/trbtstat.htm> (1.11.2000). 
Böylece, nasıl ki hemen hemen bütün ulusal hukuk düzenlerinde örneğin konusu ahlaka aykın olan sözleşmeler batıl sayılmakta ise, uluslararası hukukta da uluslararası toplumun temel değerlerine aykın sözleşmelerin yapılması ve uygulanmasının önüne geçilmek istenmèktedir. ${ }^{2}$ Daha açik bir ifadeyle, bu tür kurallar, hem ulusal hem de uluslararası hukuk düzenlerinde, toplumun temel nitelikteki çkarlannun bireylerin çkarlanna üstün gelmesinin ve bu gibi durumlarda toplumun bireysel iradeyi geçersiz kulabilmesinin yolunu açmaktadır.

Burada hemen belirtmek gerekir ki, bu tip bir kurum, ancak şok iyi örgütlenmiş ve özellikle de temel değerlerini (önceden) açk bir şekilde saptamış bir toplumda amacina hizmet eder sekilde uygulanabilecektir. Zaten, uluslararası hukukta jus cogens kuralların varlığına öğretide yapılan en önemli itirazlar da bu konu üzerinde yoğunlaşmakta ve uluslararası toplumun bugünkü yapısı itibariyle anılan şekilde kurallara hazır olmak bir yana tersine bu kuralların kötüye kullanılmasının kaçınılmaz olacağı bir yapı özelliği isşıdığı savunulmaktadır. ${ }^{3}$ Bu bağlamda, uluslararası hukukun yapısı gereği hiyerarşik bir yapılanmaya elverişli olmadığ1 görüşü, üstün/öncelikli kurallar karşıł ekolün kuramsal dayanağını oluşturmaktadır. ${ }^{4}$ Diğer yandan, bu tür düzenlemelerin devletlerin antlaşma yapma iradelerini kısitlayıcı sonuçlar doğuracak olması da özellikle iradeci görüşü benimseyen yazarlarca eleştirilmektedir. ${ }^{5}$

1969 Viyana Antlaşmalar Hukuku Säzleşmesi'yle en azından kavrameal olarak uluslararas hukuk literatürüne giren jus cogens kavramının niteligi söz konusu Sözleşme'nin 53 ve 64. maddeleri ışığında değerlendirildiğinde, her ne kadar içeriği ve somut örnckleri uygulamada, içtihatta ve hatta öğretide hala netliğe kavuşmamış olsa da, özellikle doğal hukukçular tarafından uzun süredir dile getirilen daha doğrusu "temenni edilen" bir yapllanmanın işaretlerini görmek olanaklıdır. Nitekim, uluslararası hukuk içerisinde iç hukuk benzeri dikey bir yapılanmanın yolu açlmakta ve hiyerarşik olarak daha alt seviyede

2 Bu konuda bkz.( von VERDROSS, 1937: 573-574). Hatta, Verdross, bu bağlamda uluslararası toplumda etiğin yerine dikkat çekmekte ve çok yerinde bir tespitle uluslararası toplumun minimum etik değerlerinin yerleştirilmesinin jus cogens kuralların geleceği açısından büyük önem taşıdığını vurgulamaktadır.

3 Schwarzenberger, bu tür kurallann ancak ulusüstü yetkili bir otorite ya da merkezileşmis bir güç tarafindan uygulanabileceğine dikkat çekerek uluslararası toplumun bugünkü yapısıyla henüz bu derecede örgütlenmis olmadığını ve uluslararası toplumda bir üst otoritenin bulunmadığını vurgulamaktadır. Aynca, bu tür gelişmelerin bir devletlin uluslararası polisliğe soyunmasıñn yolunu açtığını da savlamaktadır (SCHWARZENBERGER, 1971: 39-40).

4 Uluslararası hukuk düzeni içerisinde hiyerarşik bir yapılanmaya karşı çıkan görüşün en önemli temsilcisi Prosper Weil'in ilgili çalışması için bkz. Weil, 1983.

5 Bu yaklaşıma göre, jus cogens nitelikli kurallar içerenler dahil tüm antlaşmalar ancak taraflar ve bu antlaşmanın düzenlemelerini kabul eden devletler için bağlayıcıdır (SCHWARZENBERGER, 1971: 32-33). 
bulunan kuralların (inferior rules) çerçevesini çizen temel ilkeler (superior rules) tanitılmaktadır (ROZAKIS, 1976: 19-20). Her ne kadar BM Antlaşması için de "uluslararası toplumun anayasasi" gibi ifadeler kullanisa ve söz konusu antlaşmanin 103. maddesi de bu görüşü destekler görünse de, kendisiyle çatşan antlaşmalara karşı BM Antlaşması'nun (uygulamada) bir üstünlük kazanmasını sağlayan 103. maddenin tersine, bir jus cogens kuralla çatışan antlaşmaları geçersiz kılan 1969 Sözleşmesi'nin 53 ve 64. maddelerinin çok farklı nitelikte oldukları açıktı. ${ }^{6}$ Daha önce de belirtildiği gibi, bu kadar önemli sonuçlar atfedilen jus cogens kuralların bu niteliğinin nedeninin, bizatihi kendi önemlerinde yattığı ve uluslararası hukukun temel çıkar ve ilkelerini yansıtan bu tür kurallara ("toplumsal iradeye") aykurı bireysel iradelere izin verilemeyeceği belirtilmektedir (ROZAKIS, 1976: 19-20).

\section{Jus cogens Kuralların Varlığı Sorunu}

Jus cogens kurallarla ilgili incelemeye geçmezden önce, bu tür kuralların var olup olmadığının irdelenmesi yerinde olacaktır. Bilindiği gibi, 1969 Sözleşmesi'ne bütün dünya devletleri taraf değildir. Bu nedenle, içerdiği düzenlemelerin sadece taraf devletleri bağlayacağı açıktur. Diğer yandan, Sözleşme'nin giriş kısmında da belirtildiği gibi (VERDROSS, 1966: 58), Sözleşme'nin kimi maddeleri Sözleşme'den önce de mevcut olan yapılageliş kurallarıdır ve Sözleşme onları kodifiye etmiştir. Kısacası, Sözleşme'den bağımsız olarak bir varlığa sahip olan bu kurallar, Sözleşme'ye taraf olsun olmasın o yapılageliş kuralıyla bağlı olan tüm devletler için bağlayıadır. Diğer yandan, ilk kez Sözleşme'yle düzenlenen kimi kuralların da yeni bir yapılageliş kuralı yaratması ve bu haliyle taraf olmayan devletler için de bağlayıcı olması olasıdır. Bu iki niteliğe sahip olmayan Sözleşme kuralları ise, sadece Sözleşme'ye taraf olan devletler için bağlayııı olacaktır.

Burada temel soru, jus cogens kurallarla ilgili düzenlemelerin 1969 Sözleşmesi'ne taraf olmayan devletler için de bağlayıcı olup olamayacağıdır. 1969 Sözleşmesi'nde jus cogens kurallar konusunda yapılan düzenlemelerin taraf olmayan devletler için de bağlayıd olabilmesi, jus cogens kuralların varlığıyla ilgili düzenlemelerin Sözleşme'den önce, Sözleşme'yle birlikte ya da Sözleşme'den sonra yapılageliş niteliği kazanmasıyla olanaklıdır. Aşağıda da değinileceği gibi, Sözleşme'nin jus cogens kurallarla ilgili düzenlemesi, uluslararası hukukta devletlerin sözleşme serbestisini sınırlayan ve aykırı antlaşmaları geçersiz klan üstün/öncelikli kuralların varlığını tanıtmayla sunırlıdır ve somut bir jus cogens kuraldan bahsedilmemiştir.

6 Diğer yandan, geçersizlik veya sona ermeyle sonuçlanabilecek sürecin başlatılması yetkisinin sadece tarafların bırakılmıs olması dikkat çekicidir. Bu durum, aşağıda ayrıntıı olarak değerlendirilecektir. 
Içtihada ve doktrine baktı̆̆ımızda, uluslararası toplumun üstün/öncelikli kurallarınun varlığı konusunda 1969 Sözleşmesi'nden çok öncelere uzanan önemli görüşlerin olduğu görülmektedir. Uluslararası hukuk literatürünün ilk önemli kaynaklan olan eserlerinde, C. Wolff ve E. Vattel, devletlerin antlaşmalarla hukuku çğneyemeyeceğini belirtmişlerdir. Çeşitli tarţ̧̧malara konu olan bu görüşler, özellikle savaş gibi geniş kapsamlı sorunlara bağlı olarak gündeme gelmiştir. Özellikle lkinci Dünya Savaşı'nun hemen öncesinde başlayan ve Soğuk Savaş döneminde huzlanarak artan çalışmalarda jus cogens kurallar önemli ölçüde kabul görmüştür.?

1969 Sözleşmesi' yle getirilen bu yeni düzenlemenin niteliği ise, yapılageliş kurallarının özellikleri bağlamında değerlendirilmelidir. Çünkü, bu tür bir kuralın varlık kazanabilmesi ancak tüm devletler için bağlayıc olmasıyla olanaklı olabilecektir. Nitekim, hem mevcut uluslararası yapılageliş kuralların kodifiye edilmesi hem de Sözleşme'nin düzenlemesinin bir yapılageliş kuralı haline gelmesi (progressive development of intermational law) durumlarında devletlerin itiraza olup olmamaları önem kazanmaktadır. 1969 Sözleşmesi'nin kesinleşmemiş tasarısının görüşmeleri sırasında devletlerin temsilcileri tarafından dile getirilen resmi görüşlere baktığımızda, Uluslararası Hukuk Komisyonu'nun ilgili yorumunda da belirttiği gibi (YbILC, 1966: 23), uluslararası hukuk düzeninde üstün/öncelikli kuralların olmasına Lüksemburg dışında kesin olarak itiraz eden bir devlete rastlanmamaktadır.

Pek çok devlet, konuyla ilgili görüşlerini Sözleşmenin kesinleşmemiş tasarısınun komisyonda görüşülmesi sırasında açıklamıştır. Lüksemburg, egemen devletlerden oluşan uluslararası toplumda siyasi ve hukuksal otoritenin olmadığın ve bu nedenle de bu kuralların bazı devletlerin adalet ve ahlak dayatmasına zemin hazırlayacağın savunmuş ve uluslararası hukukun mevcut durumunda bu tür kurallarn olanaklı olmadığın ileri sürmüştür (YbILC, 1966: 20-21). tlgili maddelere karşı çikan diğer devletler ise, uluslararası hukukun egemen devletlerce açıklanan rizaya dayandığın ${ }^{8}$ ve bu tür kuralların ulusal hukuklardaki gibi bir kaynak hiyerarşisine sahip olmayan uluslararası hukuka aktarımasının olanaklı olmadığın dile getirmiştir. ${ }^{9}$ Önerilen bu tür kuralların içeriğinin muğlak olduğu ${ }^{10}$ ve özellikle örnek verilmemesinin antlaşmaların

7 Jus cogens kuralların varlığı yönündeki görüşler için bkz. (TUNKIN, 1974: 147-160; BROWNLIE, 1990: 512-515; RAGAZZI, 1997: 44-45).

8 Örneğin, Fransa (UN, 1970: 93); ve Türkiye (UN, 1970: 99).

9 Örneğin, Türkiye (UN, 1970: 99). Türkiye, diğer yandan, bu kurallann ilk bakışta uluslararası toplum için önemli ve yararlı olduğunu ama zonunlu yargı olmadan yeni yanlı̧ anlamalara neden olunacağını belirtmistir (YbILC, 1966: 21). Konuyu Türkiye açısından değerlendiren ve Kıbrıs sorunu konusundaki yansımalarını ele alan bir çalışma için bkz. (TOLUNER, 1977: 185-195).

10 Örneğin, Avusturya (UN, 1970: 95). 
istikran açsından yeterli garantiyi sağlanmadığ 11 da diğer itiraz noktalan olmuştur.

Diğer yandan, devletlerin çok önemli bir çoğunluğu 12 ilgili düzenlemeyi desteklemiş ve bu tür kuralların uluslararası toplumun ilerlemesi açısından yaşamsal öneme sahip olduğu görüşü yaygın şekilde dile getirilmiştir. ${ }^{13} \mathrm{Kimi}$ devletler bu tür kuralların uluslararası toplumda zaten öteden beri var olduğunu dile getirirken ${ }^{14}$ kimisi de bu tür kuralların uluslararası toplumun mevcut gelişmesinin kaçınlmaz bir sonucu olarak değerlendirmiştir. ${ }^{15}$ Düzenlemeyi destekleyen devletlerden bazıları, muğlaklık ve örnek olmaması konulanında yapılan itirazlara karşı q $\mathrm{kmmış} \mathrm{ve} \mathrm{özellikle} \mathrm{BM} \mathrm{Antlaşması'nın} 1$ ve 2. maddelerinde geçen amą̧ ve ilkeleri jus cogens kuralların en önemli örnekleri olarak değerlendirmiştir. ${ }^{16}$ Görüldü̈ü gibi, devletlerin çok önemli bir kısmı jus cogens kurallanın varlığın (yani bir sözleşmeyle kodifiye edilmesinin yerinde olacağınu) ya da gerekliliğini (yani, bir sözleşmeyle uluslararası hukuka kazandırılması gerektiğini) kabul etmektedir. Nitekim, her toplumda kimi temel kuralların olmasının gerektiğini ve örneğin köle ticaretinin yasaklanmasının bir jus cogens kural olarak değerlendirilmesine kimsenin karşı çkmayacağını belirten Ingiltere, içcrikle ilgili muğlaklıklardan ve düzenlemenin kimi uç örneklere neden olma tehlikesi taşımasından dolayı bu maddeyi kabul etmeyeceğini açıklamıştır. Ingiltere, diğer yandan, devletlerin çoğunluğunun bu endişeleri taşımıyor olduğunu ve maddenin sözleşme tasarısının kilit maddesi durumuna geldiğini belirterek maddeye ret oyu vermek yerine çekimser kalacağın açıklamıştır (UN, 1970: 97-98).

Kimi uluslararası yargı ve hakemlik organlarında da özellikle yargıçların ayn veya karşı görüşlerinde ve bazı taraflann savunma ve açıklamalarında jus

11 Örneğin, Türkiye (UN, 1970: 99) ve Fransa (UN, 1970: 94).

12 Örneğin, ABD, Brezilya, Bulgaristan, Birleşik Arap Emirlikleri, Cekoslavakya, Ekvador, Endonezya, Fas, Filipinler, Fransa, Gana, Guetemala, Irak, Italya, Ispanya, Macaristan, Panama, Sovyetler Birliği, Polonya, Romanya, Suriye, Tayland, Ukrayna, Uruguay, Venezuella, Yugoslavya (YbILC, 1966: 22-23)

13 Örneğin, Filipinler (UN, 1970: 95); Kolombiya (UN, 1970: s98); Polonya (UN, 1970: 99); F. Almanya, (UN, 1970: 95-96); Ekvador (UN, 1970: 96); Venezuella (YbLC, 1966: 23); Yugoslavya (YbILC, 1966: 23); Romanya (UN, 1970: 97 ).

14 Ekvador (UN, 1970: 96). Ekvadorun dile getirdiği görüşler gerçekten dikkat çekicidir. Bu tür kurallann uluslararası hukukta zaten olduğunu savunan Ekvador, diğer yandan, kodifikasyon özelliği taşıdı̆ıın belirttiği ilgili maddenin Sözleşme yürürlüğe girdikten sonra bağlayıcı olacak olmasını eleştirmekte ve bu düzenlemenin devletlere Sözleşme yürürlüğe girene kadar istedikleri yapma konusunda bir serbesti tanıyacağını belirtmiştir. Bu tür kurallara herkesin uymasınun gerekliliğine dikkat çeken Ekvador, tamamen temelsiz olan itirazların nedeninin siyasi çıkarları ve haksız elde edilmis avantajlan sürdürme arzusu olduğunu ileri sürmüştür (UN, 1970: 96-97).

15 Örneğin, Kamerun (UN, 1970: 98); Kolombiya (UN, 1970: 98).

16 Örneğin, Ekvador (UN, 1970: 96); Küba (UN, 1970: 97); BAE (YbILC, 1966: 23); Fas (YbILC, 1966: 22); Ukrayna (UN, 1970: 100). 
cogens kurallara atf yapılmıştır. UAD, kararlannda, jus cogens kuralların varlığı veya içeriği konusunda doğrudan bir yorum yapmamayı tecih eder bir görüntü çizmektedir. Ne var ki, "uluslararası toplumun temel kurallar" ya da "uluslararası toplumun öncelikli kurallar" gibi ifadelere UAD kararlannda ve yargıçlann ekli görüşlerinde rastlamak olanaklıdır.

Bunun ilk örneği olarak, UAD'nin Soykurum Sözleşmesi konusunda verdiği danışma görüşü anulmaktadır. ${ }^{17}$ Divan, insanlığı tehdit eden ${ }^{18}$ soykınımin, ahlaki hukuka (moral law) ve BM Antlaşmasi'nun amaç ve ruhuna aykırı olduğunu belirtmiştir. Divan, aynca, söz konusu Sözleşme'de yer alan ilkelerin, uygar ülkelerce, herhangi bir bağıtsal (ahdî) yüküm olmadan da bağlayıcı kabul edildiğine dikkat çekmiş ve bu ilkelerin tek tek devletlerin çıkarların ilgilendirmekten çok uluslararası toplumun ortak çkarına olduğunu vurgulamıştur. Divan'a göre, bu özelliklere sahip bir Sözleşme, hem çekince koyma hem de bu amaçlara itiraz etme özgürlüğünü sınırlamaktadır. Divan, bu çerçevede, devletlerin, egemenliklerinin bir sonucu olarak Sözleşme'ye çekince koyarak taraf olabileceklerini görüşünü, Sözleşme'nin amaa nedeniyle, reddetmiştir (YbILC, 1966: 23-24). Divan'ın bu görüşü, uluslararası toplumun temel ve öncelikli kurallarının her zaman mevcut olduğunun ve bu kuralların devletlerin egemenliğine (yani, irade serbestisine) üstün geldiğinin önemli bir kanit $^{19}$ olsa gerektir.

UAD, Military and Paramilitary Activities In and Against Nicaragua Davasz 27 Haziran 1986'da verdiği karannda, Uluslararası Hukuk Komisyonu'nda yapılan çalışmalar sırasında Komisyon'un BM Antlaşması 2/4. maddesinde ifadesini bulan kuvvet kullanma ve kuvvet kullanma tehdidi yasağın jus cogens kurallara örnek olarak olarak saydığını ve tarafların da açıklamalarında ve sunduklan savunmalarda bu yasağın jus cogens kural olduğunu dile getirdiklerini belirtmiştir (paragraf 190). Hatta, UAD'nun o dönemki başkanı Yargı̨̧ Singh, karara ekli görüşünde, Divan'ın bu ifade yoluyla kuvvet kullanma yasağının jus cogens kural olduğunu teyit ettiğini belirtmiştir. ${ }^{20}$

UAD, Legality of the Threat or Use of Nuclear Weapons Davasinda verdiği karannda ise, (ICJ Reports, 1996), kuvvet kullanma ve kuvvet kullanma tehdidi konusundaki yasağı uluslararası yapılageliş hukukunun çiğnenemez

17 Örneğin, Ekvador, bu davaya atıf yaparak uluslararası toplumun bu tür kurallara zaten sahip olduğunu savunmuştur (bkz. UN, 1970: 96).

18 Divan, bu danışma görüşünden iki yıl önce Corfu Davasinda verdiği karannda ise, insanlığın temel düşünceleri (elementary considerations of humanity) ifadesini kullanmıştır.

19 UAD Statüsü'nün 38. maddesi, " $\mathrm{d}$ " fikrasında, uluslararası yargı kararların, uluslararası hukukun varlığını ve içeriğini saptayan kurumlar (law-determining agencies) arasında saymıştır.

20 Mahkeme karanın ve yargıçann ekli ayn ve karşıt görüşleri için bkz. <http://www.icj-cij.org/icjwww/idecisions/isummaries/inussummary860627.htm> (10.11.2000) 
(intransgessible) ilkesi olarak değerlendirmiştir (paragraf 79). Her ne kadar burada ilgili yasak yapılageliş hukukunun bir parçası olarak değerlendirilmişse de, açıktır ki, yapılageliş kuralları "çiğnenemezlik" özelliği taşımadığından, UAD'nin bu vurgusu, hem ilgili yasağın uluslararası hukukun klasik kurallarından bir farklılığı olduğunu göstermekte hem de bu farklıhı̆gın niteliğini (jus cogens kuralların temelinde yatan mantıkla açklayarak) işaret etmektedir.

1997 yulında Macaristan'la Slovakya arasındaki Gabcikovo/Nagymaros uyuşmazlığı konusunda verilen kararda ise (paragraf 112), tarafların hiçbirisinin ilgili 1977 Antlaşması'nın imzalanmasından sonra çevre hukukunun öncelikli bir kuralınun oluştuğunu ileri sürmediğini onun için de Viyana Antlaşması'nun 64. maddesinin kapsamın incelemesine gerek olmadığını belirtmiştir. Söz konusu madds, "genel uluslararast hukukun yeni bir buyruk kuralı oluştuğunda, bununla çatışan yürürlükteki her antlaşma batıl olur ve sona erer," şeklindedir. Divan, yeni ortaya çlkan jus cogens kuralların varlığının daha önceden yürürlüğe giren bir antlaşmaya etkisini değerlendirmesine gerek olmadığından bahsederek, ayn Sözleşme'nin 53. maddesinde öngörülen jus cogens kuralların varlığını zımnen kabul etmiştir. Açktır ki, "yeni jus cogens kural oluştu, o çerçevede değerlendirme yapılmal,," isteği gelmediğini onun için yeni ortaya çıan bir jus cogens kuralların mevcut antlaşmalara (olası) etkisini incelemesine gerek olmadığın belirten Divan, eğer jus cogens kuralların varlığından kuşku duysa, "jus cogens kuralların varlı̆gn ve eğer varlarsa etkilerini incelemekten" bahsedebilirdi.

Özellikle son yıllarda yargıçlann ekli görüşlerinde jus cogens kuralların varlığı konusu daha fazla yer almaktadır. Örneğin, Yargı̨̧ Weeramantry, Ispanya'yla Kanada arasındaki Balıkçıluk Davası karanna (4 Aralık 1998) ekli karşıt görüşünde $(25,31$, ve 40. paragraflar) ve özellikle de Nükleer Silahların Kullanımının Hukuksallığı Davası kararına (8 Temmuz 1996) ekli karşıt görüşünün III. Bölümünün 10. başlığında, açıkça jus cogens kuralların varlığın dile getirmiştir. Yargıç Koroma da, Nükleer Silahların Kullanımının Hukuksallığı kararında ekli görüşünde, sivillere zarar vercbilecek saldırıların askeri gereklilikle dahi açlklanamayacak şekilde öncelikli kurallar olduğunu belirtmiştir. Yargı̨̧ Sette-Camara ise, Military and Paramilitary Activities in and Against Nicaragua Davası kararına ekli 27 Haziran 1986 tarihli karsıt görüşünde, kuvvet kullanma ve kuvvet kullanma tehdidinin kararda belirtildiği gibi uluslararası hukukun sadece temel kuralları olmakla kalmadığını, ayn zamanda tüm devletlere yükümlülük getiren öncelikli kurallar arasında yer aldığını belirtmiştir.

Bazı devletlerin UAD'ye yaptıklan başvurularda ya da dava surasında yaptıkları savunmalarda ve açıklamalarda da jus cogens kuralların varlığın esas alan ifadeler yer almaktadır. Örneğin, yukarıda da belirtildiği gibi, Military and 
Paramilitary Activities in and Against Nicaragua Davasinda, iki taraf da (Nikaragua ve $A B D$ ), kuvvet kullanma ve kuvvet kullanma tehdidi kosundaki yasağı jus cogens kural olarak değerlendirmişlerdir. Ispanya'yla Kanada arasındaki Balıkçılık Davası sırasında dă, taraflar, çeşitli aşamalarda yaptıkları açılamalarda, BM Antlaşması'nın 2/4. maddesinde ifadesini bulan kuvvet kullanma ve kuvvet kullanma tehdidi konusunda yasağın jus cogens kural olduğunu belirtmişlerdir. ${ }^{21}$

Diğer yandan, örneğin Uluslararası Hukuk Komisyonu'nun halen sürdürmekte olduğu çalışmalar sonucu hazırladığı devletlerin sorumluluğu konusundaki taslak sözleşmenin 33/2. maddesinde 22 , sorumluluğu ortadan kaldıran gereklilik halinin ileri sürülemeyeceği durumlar arasında "uyulmayan söz konusu yükümlülüğün uluslararası hukukun öncelikli bir kurah olması," da sayılmaktadır (a bendi). Uluslararası Hukuk Komisyonu'nun "Insan Hakları Antlaşmalarını da Içeren Çok Taraflı Normatif Antlaşmalara Çekince Koyma" konusundaki ilk çalışmasında ${ }^{23} \mathrm{da}$, yapılageliş kurallarıyla birlikte jus rogens kurallara da çekince koyulup koyulamayacağı gündeme gelmiş (paragraf 106) ve yapılageliş kuralları konusunda olumlu görüş belirtilirken, jus cogens kurallar konusunda ise bu kuralların özelliği gereği sadece o kuralın ilgili antlaşmada yer almasına çekince koyulabileceği belirtilmiştir. Aynca, jus cogens kuralların devletlerin aralarında anlaşmasından etkilenmeyeceği ve bunlara konulan çckincelerin de bir etkisi olmayacağı vurgulanmıştır. Bu iki örnek, jus cogens kuralların uluslararası toplumda ilgili yeni düzenlemelerde temel alınacak ölçüde benimsendiğinin önemli göstergeleridir.

Ayrica, doktrinde de bu konuda genel bir fikir birliğinin olduğu görülmektedir. Uluslararası hukuk normları arasında bir hiycrarşinin olduğu ön kabulünü esas alan jus cogens kurallann varlığına en önemli itiraz, yukarıda da belirtildiği gibi, uluslararası hukuk normları arasında hiyerarşi olamayacağı görüşünden gelmektedir. Bu görüşe göre, "norm" ve "daha norm" diye bir ayrm yapmak olanaksız olacağından ve bağlayıclulık açsından tüm normlar eşit olacağından (yani, ya bağlayıc ya da değil), uluslararası hukuk kuralları arasında bir ayrım yapmak ve bir dizi kuralı diğerlerinin çerçevesini belirleme yetkisiyle donatılmıs şckilde onların üzerine yerleştirmek olanaklı değildir. ${ }^{24}$

21 Örneğin, Ispanya'run Eylül 1995'te Kanada'nun da 15 Haziran 1998'te yaptığı savunmalar (Savunmaların metni için bkr. <http://www.icj-cij.org/icjwww/idocket/iec/ iecframe.htm> 10.11.2000).

22 Uluslararası Hukuk Komisyonu'nun 1996 Raporunun üçüncü bölümünde yer alan taslak sözleşmenin metni için bkz. <http://www.un.org/law/ilc/reports/1996/ chap03.htm\#doc38> (1.11.2000).

23 Metni için bkz. <http://www.un.org/law/ilc/reports/1997/chap5.htm\#conclusions> $(1.11 .2000)$.

24 Bu konuda bkz. (WEIL, 1983). Bu esere karşılık olarak yazılan makale için ise bkz.. (FASTENRATH, 1993). 
Öte yandan, uluslararası hukuk kuralların yaratan kaynaklar arasinda bir hiyerarşi kurmanin uluslararası toplumun ve uluslararası hukukun yapısı gereği de olanaksız olduğu savunulmakta ve bu çerçevede uluslararası hukukun sadece egemen eşit devletlerin iradelerinden kaynaklandığı ve bu kaynakta hiyerarşi olamayacağına göre üstün/öncelikli kuralların yaratılmasının da söz konusu olamayacağı savunulmaktadır (WEIL, 1983). ${ }^{25} \mathrm{Ne}$ var ki, jus cogens kurallara bu niteliğini veren, aşağıda ilgili başık altında da inceleneceği gibi, içerdikleri kurala atfedilen niteliktir; kendilerini yaratan kaynağın üstünlüğü ya da farklulığı değil. ${ }^{26}$ Bir başka ifadeyle, jus cogens kurallara üstünlük veren, içerdikleri normun toplumsal değeridir. Nitekim, ulusal hukuklarda da Anayasalarn durumu bundan pek farkl değildir. Anayasalar, (demokratik sistemlerde) çok yaygın bir şekilde, diğer "sıradan" kuralları (yasaları) yaratan kaynak yani parlamentolar tarafindan hazırlanmaktadır. Diğer yandan, Anayasalann kabulü de ya toplumu temsil ettiği varsayılan parlamentolarda diğer yasalara ve düzenlemelere göre daha fazla çoğunluk oyuyla gerçekleşmekte ya da halkoyuna sunma gibi toplumsal değeri (daha) doğrudan yansitan yöntemler tercih edilmektedir. Tek fark, diğer "sıradan" yasaları kabul ederken genelde basit çoğunluk aranurken, Anayasa gibi temel konularda, nitelikli çoğunluğun kabul oyu vermesi istenmektedir. Kısacası, Anayasalara bu niteliğini veren onlan yaratan kaynağın farklılı̆̆ değil, kendilerine atfedilen değerdir. Bu nedenle, uluslararası toplumun egemen devletlerin eşitliğine dayalı olması nedeniyle hiyerarşik kuralların yaratılmasına elverişli olmadığını söylemek pek yerinde görünmemektedir.

Sonuç olarak, 1969 Sözleşmesi'nde ifade bulduğu şekliyle jus cogens kuralların varlığının bir yapılageliş kuralı olarak bütün devletleri bağladığın söylemek yanlı̧ olmayacaktır. Diğer yandan, insan haklan, kuvvet kullanmanın yasaklanması, köle ticareti ve açk denizlerin scrbestliği gibi çok yaygın önerilere rağmen, hangi kuralların jus cogens nitelikli kurallar olduğu konusunda aynı şeyleri söylemek olanaklı değildir. Kısacası, somut bir jus cogens kuraldan bahsetmek, jus cogens nitelikli kuralların varlğından bahsetmek kadar kolay değildir. Yine de, üzerinde çok yaygın bir görüş birliği olan ve uluslararası sistemin temel sigortasını teşkil eden kuvvet kullanma yasağının bu kapsamda değerlendirilmesi yanlıs olmasa gerektir.

25 Lüksemburg (YbILC, 1966: 20-21) ve Türkiye (UN, 1970: 99) de Uluslararası Hukuk Komisyonu'nda yapılan görüşmeler sırasında bu görüşü dile getirmişlerdir.

26 Benzer bir gönüş Uluslararası l lukuk Komisyonu'ndaki görüşmelerde Küba tarafından da dile getirilmiştir (UN, 1970: 97). 


\section{1969 Viyana Antlaşmalar Hukuku Sōzleşmesi'nde Jus cogens Kurallar}

\section{A. 1969 Sözleşmesi'nin ligill Düzenlemeleri}

Öğretide daha eskilere uzanan jus cogens kurallarla ilgili görüşlerin ${ }^{27}$ resmi zeminlerde etki doğurması sonucunda "üstün/öncelikli" niteliğe sahip kimi kuralların pozitif uluslararası hukuka kazandırıması çalışmaları huz kazanmıştır. Birleşmiş Milletter Uluslararası Hukuk Komisyonu'nca hazırlanan antlaşmalar hukuku sözleşmesi taslağında yer alan jus cogens kurallarla ilgili düzenleme 1969'da Viyana'da imzalanan Sözleşme'de de büyük ölçüde korunmuştur. Sözleşme'nin jus cogens kuralların tanumin yapan ve "Antlaşmalann Geçersizliği" başlıklı bölümde ele alınan 53. maddesi şöyledir:

Yapılışı sırasında genel uluslararası hukukun bir buyruk kuralıyla çatışan her antlaşma batıldır. Bu sözleşmenin amaçlan bakımından genel uluslararası hukukun buyruk kuralı, devletlerin uluslararası topluluğunun bütününce aksine hiçbir kuralın konulması olanağı bulunmadığı ve ancak genel uluslararası hukukun aynı nitelikteki yeni bir kuralıyla değiştirilebileceği kabul edilen ve tanınan kuraldır.

Sözleşme'nin "Antlaşmaların Sona Erdirilmesi ve Yürürlüğünün Askıya Alınması" başlıklı bölümünde yer alan 64 . maddesi ise, yeni jus cogens kurallann oluşması durumunun bu yeni kuralla çațşan önceki antlaşmalara etkisini düzenlemektedir:

Genel uluslararası hukukun yeni bir buyruk kuralı oluştuğunda, bununla çatışan yürürlükteki her antlaşma batıl olur ve sona erer.

\section{B. Sözleşme'ye Göre Jus cogens Kuralların Oluşumu ve lçeriğl}

1969 Sözleşmesi'nin jus cogens kuralların tanumı konusunda düzenleme yapan maddesinde (madde 53), "devletlerin uluslararası topluluğunun bütününce aksine hiçbir kuralın konulması olanağı bulunmadığı ve ancak genel uluslararası hukukun ayn nitelikteki yeni bir kuralıyla değiştirilebileceği kabul edilen ve tanınan kural," olarak tanımlanmıştır. Bu tanıma göre jus cogens kurallar üç özelliğe sahiptir: öncelikli niteliği sahip genel uluslararası hukuk kuralı olma; devletlerin uluslararası topluluğunun bir bütün olarak kabul etmesi ve kendisinden sapmanin olanaklı olmaması; ve ancak aynı nitelikteki bir başka kuralca değiştirilebilme.

$\mathrm{Bu}$ üç özellikle ilgili aynnthl incelemeye geçmezden önce bu incelemelerde de göz önünde bulundurulacak bir gelişmeyi vurgulamak yerinde olacaktur. Jus cogens kurallara tanumsal olarak yer veren Sözleşme, 
komisyonda ve görüşmelerde yapılan tartışmalara rağmen hem bu tanımlamayı pekiştirecek hem de somut uygulamaya zemin hazırlayacak şekilde bir örnek vermemiştir. Nitekim, özellikle BM Antlaşması'nın 2/4. maddesinde ifadesini bulan kuvvet kullanma yasağı bu bağlamda gündeme gelmiştir. Ne var ki, kimi yazarların eğer jus cogens kural diye bir kural çeşidi varsa söz konusu maddede düzenlenen kuvvet kullanma yasağınn buna en iyi örnck olacağı şeklindeki görüşleri bir yana, 1969 Sözleşmesi'nde herhangi bir örnek verilmesinden kaçınulmıştr. Komisyon, ilgili yorumunda, içeriğin ve örneklerin uygulama ve içtihata bırakıldığın belirtmiş (UN, 1971: 67) ve bu tutumunun gerekçesi olarak da, maddede sayılmayacak kimi kuralların durumuna ilişkin olarak yanlış anlamalara neden olma endişesini ve jus cogens kural olarak nitelenecekler konusunda da çalışmanin boyutunu aşacak ek incelemelerin gerekli olabilecek olmasını göstermiştir (UN, 1971: 68).

\section{1. "Öncelikli Niteliğe Sahip Olma"}

Jus cogens kurallann en önemli özelliği, öncelikli niteliğe sahip uluslararası hukuk kuralı olmalarıdır. Burada hemen yantlanması gereken soru, uluslararası hukuk düzeninde öncelikli kuralların yer alıp alamayacağıdır. Bir başka ifadeyle, uluslararası hukuk düzeninin öncelikli kurallar içermeye elverişli olup olmadığıdır.

Uluslararası hukuk sistemi içerisinde de öncelikli kuralların olduğu /olması gerektiği görüşünün hareket noktası, ulusal hukuklarda yer alan "kamu düzeni" olgusudur. Nitekim, bir çok ulusal hukuk sisteminde28, bireylerden oluşan toplumun (ulus) yine bireylerden kaynaklanan genel değerlerini yansıttı̆ı varsayılan değerler toplamı, uygulamada bircylerin irade özgürlüğünü sınurlamakta ve bireyler, ancak bu kurallar çerçevesinde hareket özgürlüğünden yararlanabilmektedir. Bu değerlerin mantıksal gerekçesi ise, "insanların toplum içinde yaşamak zorunda oldukları," varsayımıdır. Buna göre, insanlar, ancak toplum içinde hemcinsleriyle dayanışma halinde yaşayabilirler. Mutlu ve refah içinde bir yaşam için gerekli olan toplumun varolması ve sürdürülmesi ise belirli temel kurallara uyulmasıyla olanaklıdır. Buna "toplumun çıkarı" demek de olanaklıdır. Böylece, her toplumda, toplumun temel nitelikli çkarlarının bireylerin çıkarları üzerinde yer aldığı kabul edilmekte ve bireylerin özgürlüğü, bu temel kuralların çizdiği çerçeveyi ihlal etmedikleri sürece söz konusu olabilmektedir. Hemen tekrar vurgulamak gerekir ki, toplumun çıkarları olarak adlandırılan kural ve ilkeler, ancak bireylerin çok önemli bir kısmının (yani, bütünün) bu yönde düşündüğü

28 Her ulusal hukuk sisteminin bir üst kimlik etrafında toplanan/bütünleşen bireylerden oluştuğu varsayılmaktadır. Bir başka ifadeyle, ulusal hukuk sistemleri (görece) "homojen" toplumlann ürünüdür. 
varsayımına dayanmaktadır. Başka bir ifadeyle, karşı düşünceler o düzcydedir ki, bütünün bütün olma özelliğini boz(a)mamaktadır.

Bu varsayumın bir başka olmazsa olmaz koşulu ise, ikincil nitelikteki kuralların (inferior rules) çerçevesini çizen öncelikli/üstün kuralların (superior rules) gözetilmesini sağlayacak üst/merkezi otoritedir. Söz konusu birimin bir toplum olabilmesi için de gerekli olan üst otoritenin varlığı koşulu, öncelikli kuralların uygulanmasının temel aracıdır. Açıktı ki, bu tür kuralların tespiti ve uygulanması önemli aşamalardır. Bununla birlikte, temel sorun bu kurallara uyumun sağlanması yani uyumun gözlenmesi ve uyulmama durumunda gerekli önlemlerin (yaptırım) alınp uygulanabilmesidir. Bu ise, yargılama yetkisine sahip bir kurumun varlığın gerektirir. Ulusal hukuk sistemleri bağlamında düşünmek gerekirse, devletin üç temel işlevinden (yasama, yürütme ve yarg1) yargının, toplumun varlığınun pekiştirilerck sürdürülmesindeki önemli yeri açıktır.

Konuya uluslararası toplum ve uluslararası hukuk sistemi bağlamında baktığımızda, egemen eşitlik ve barıs ilkelerine uygun olarak oluşan uluslararası toplum da, bir "toplum" olabilmenin gereklerini yerine getirmek ve varlığın pekiştirerek sürdürmek için kimi temel kurallara (superior rules) gereksinim duymaktadır. Bunlar ise, tıpkı yukarıda ulusal hukuk sistemleri bağlamında açıklanmaya çalışıldığı gibi, tek tek devletlerin çıkarlarınun bir anlamda geri plana atıldığı ve bütünün çıkarının öne çıkarıldığı durumlara işaret etmektedir. Yine hemen vurgulamak gerekir ki, burada da, devletlerin iradelerinin devre dışı bırakılması söz konusu değildir. Egemenliğe dayah geleneksel katı yaklaşım anımsandığında, bunun ulusal hukuk sistemlerine göre çok daha zor olduğu da açıktır. Bir kere, zaten öncelikli/üstün kurallarla düzenlenmeyen alanlarda devletlerin egemenlikten kaynaklanan sözleşme serbestisi sürecektir. Ne var ki, uluslararası toplumun temel değerlerinden olan kural ve ilkeleri, uluslararası toplumda o konuda oluşan homojen tavrın bu niteliğinin bozmayacak ölçckte olmasına rağmen irade zırhının arkasına saklanarak benimsememekte adeta direnen devletlerin surf bu iradeleri nedeniyle yaşama geçir(e)meme de mantıksal ve işlevsel olmasa gercktir.

Diğer yandan, yukanda da belirtildiği gibi, bu kurallara uyumun sağlanması da en az kuralların varlığının kabul edilmesi kadar önemlidir. Bir kere bu nitclikJere sahip bir kural ya da ilkenin var olduğu kabul edildikten sonra, devletlerin uygulamaları ya da yaptiklanı antlaşmalarla bunlara aykın tutum sergilemeleri durumunda bunun engellenmesi gerektiği açıtır. Nitekim, 1969 Antlaşmalar Hukuku Sözleşmesi, bu tür durumlarda aykırı antlaşmanın geçersiz (batıl) olacağın öngörmektedir (madde 53). 1969 Sözleşmesi'nin bu bağlamda öngördüğü süreç aşağıda ilgili başlık altına cle alınacaktur. Burada hemen belirtmek gerekir ki, Sözleşme'nin bu sürecin harekete geçirilmesini yine taraflara bırakması bu anlamda ciddi bir sorundur. Nitekim, hem bir devletin 
iradesi uluslararası toplumun temel bir ilke ya da kuralina aykun davranması nedeniyle o işlem için geçersiz sayılmakta hem de geşersizliğin saptanması sürecini başlatma yetkisi de yine aynı devlete bırakılmaktadır. Bu, devletlerin önemli bir kısmının hala egemenliği her şeyin (konumuz açısından, uluslararası toplumun çkarlanınun) üstünde tutmasının ve 1969 Sözleşmesi'nin getirdiği önemli bir düzenlemeyi yine kendisinin bir anlamda çalşamaz hale getirmesinin ilginç bir örneğidir.

Uluslararası toplumun bütününün temel kural ve ilkelerine saygıyı yerieştirme, bunlann kimi devletler tarafından çĭgnenmesinin önüne geçme ve öncelikli kurallar yerleştirme çabalarınun somut bir sonucu olan jus cogens kuralların uygulanması, hiç kuşkusuz, uluslararası hukukun genel sorunlarından bağımsız değildir. Devletlerin zaman zaman uluslararası hukuka uymaması ve hatta kimi temel nitclikli kurallann bile çiğnenebilmesi2 ${ }^{29}$ uluslararası hukuka olan inanc zayıflatabilmektedir. Nitekim, kimi devletlerin uluslararası hukuka uymak niyetinde olmadığını daha doğrusu uymanın fazlaca keyfi olduğunu düşünenler, uluslararası hukukun aslında olmadığın bile ileri sürebilmektedirler. Diğer yandan, bunun bir etkinlik sorunu olduğu ve uluslararası hukukun temel ilke ve kurallarının bile henüz oluşmakta olduğu dikkate alındığında sorunun uluslararası toplumdaki gelişmeye koşut olarak giderileceği söylenebilir. Gerçekten de, her ne kadar oluşmasın tam olarak tamamlamamıssa da ortada bir toplum (uluslararası toplum) olduğuna göre, onun bir hukukunun (uluslararası hukuk) ${ }^{30}$ da olduğu açıktr. ${ }^{31}$ Bu nedenle, karşılaşılan sorunlan gelişmekte olan bir hukuk sisteminin uygulamada karşılaştı̆ı sorunlar olarak kabul etmck ve etkinliği arturmaya yönclik girişimlerle bunun büyük ölçüde giderilebileceğini varsaymak yanlış olmasa gerektir. Bu ise, yukanda da belirtildiği gibi, ancak kurallara uyulmasını sağlayacak ve uyulmadığı durumlarda gerekli önlemleri alacak yapının kurulmasıyla olanaklı olacaktır. Devletlerin eşitliği ilkesi çerçevesinde kurulacak olan bir yapının bu anlamda gerekli düzenlemeleri yapabileceği düşünülebilir. Önemli olan, Birleşmiş Milletler sistemi içerisinde uluslararası barış ve güvenliği gözetmek ve bozulduğu durumlarda da yeniden tesis etmekle görevlendirilmiş olan Güvenlik Konscyi'nin kuruluşunda yapılan yanlışın tekrarlanmaması ve böylesi temel bir görevi yürütecek olan kurumun/organn uluslararası toplumun temel ilkesi olan devletlerin eşitliği ilkesine uygun bir şekilde kurulmasıdır. ${ }^{32}$

29 Özellikle kuvvet kullanma konusunda.

30 Hukuk, her boyutuyla yazılı olmak zorunda değildir. Önemli olan, bir toplum içerisinde davranıs kalıplarının düzenlenmiş olmasıdır.

31 Nerede toplum orada hukuk.

32 Ne var ki, BM Millenyum Zirvesiinde de gündeme gelen bu konuda yapılan öneri, asıl sukıntıyı gidermekten uzak görünmektedir. Güvenlik Konseyi'ndeki daimi üye sayısını artırmak seklinde formüle edilen bu önerinin zaten eşitsizlikten kaynaklanan mevcut sorunlan gidermekten çok onlara yenilerini ekler niteliktedir. 
Böylece, uluslararası toplumun bütünü tarafından varlığı kabul edilen temel kural ve ilkelere uyulması, bazı devletlerce değil yine "uluslararası toplumun bütünü"nce sağlanacaktır. Bu ise, toplumun çkarlanının, uygun konjonktür sonucu bütün adına hareket etme yetkisini bir kere eline almış olan bir grup devlete emanet edilmemesi anlamina geleceği gibi, hukukun konjonktünel güç kaymalanıa göre yorumlanmasın da engelleyecektir. Bu tür kuralların kötüye kullanulma riski içermeleri nedeniyle terk ya da inkar edilmeleri çözüm olmasa gerektir. Önemli olan, çabalann, kötüye kullanulma riskinin olanaklı olan en alt düzeyde tutulacağı bir hukuk düzeni yönünde harcanmasıdır. Açıktır ki, bu varsayımsal yapı, diğer yandan, uygulamanun takipcisi olacak ve kendiliğinden harekete geçebilecek zorunlu bir yargı organının varlığın da gerektirmektedir. Zaten, yukarıda da belirtildiği gibi, yargi işlevi, kuralların belirlenmesi (yasama) ve uygulanmasının (yürütme) sağlıklı olması koşuluyla, bir hukuk düzeninin en önemli göstergesidir.

Sonuç olarak, her hukuk düzeninde olduğu gibi uluslararası hukuk düzeni de öncelikli kuralların olmasına elverişlidir. Nasıl ki her toplumun tek tek bireylerinden bağımsız olan kimi temel değerleri bulunmaktaysa, uluslararası toplumun da tek tek devletlerin iradelerinden bağımsız olan temel değerleri vardır. ${ }^{33}$ Bu nedenle, uluslararası toplumun hukuku da temel, üstün ve öncelikli kurallara sahiptir. Kaldı ki, uluslararası hukukun temel dayanağı olduğu konusunda jus cogens kuralların gündeme gelmesinden çok öncelerden beri oldukça yaygin bir kanaat bulunan pacta sunt servanda gibi ilkeler anımsandığında, bu tür kuralların uluslararası hukuk için yeni bir durum olmadığı da açktır. ${ }^{34}$ Bu nedenle, uluslararası toplumun gelişimine koşut olarak şekillenen yeni öncelikli kuralların sistemli bir şckilde yerini almasın sağlayacak jus cogens kurallarla ilgili gelişmelerin uluslararası toplumun geleceği açısından büyük önem taşıdığı açıktır.

\section{Devletlerin Uluslararası Topluluğunun Bir Bütün Olarak Kabul EtmesI ve Kendisinden Sapmanın Olanaklı OImaması"}

"Devletlerin uluslararası topluluğunun bir bütün olarak kabul etmesi ve kendisinden sapmanın olanaklı olmaması," özelliği konusunda açğa kavuşturulması gereken noktalan şöyle sıralamak olanaklıdır: Devletlerin söz konusu kuralla bağlanma iradesini açklaması belirli bir biçime tabi midir? Bütün devletlerin mi yoksa devletlerin bütününe yakın kısmının mı bu yönde

33 De Vischer, uluslararası hukukun temel ilkelerinin varlığı konusunda şöyle bir ifade kullanmaktadır: "Deoletlerin iradelerine dayanmayacak kadar temel olan uluslararast kurallar." Aktaran kaynak için bkz. (RACAZZI, 1997: 66).

34 Verosta (SCHWELB, 1967 : 964-965) ve daha sonra da Tunkin (TUNKIN, 1974: 147-160), pacta sunt seroanda ilkesinin jus cogens niteliğe sahip olduğunu savunmuşlardır. 
iradesi gereklidir? Ikinci durum söz konusu ise, bunun niteliksel ve niceliksel kapsamı ne olmalıdır? Olası bir jus cogens kuralın getirdiği düzenlemeyle bağlanma iradesi yeterli midir, yoksa iradenin kuralın niteliğine (aykırı hiçbir kural yaratılamaması ve kendisinden sapılamaması) de yönelmiş olması mı gerekmektedir? "Kendisinden sapmanun olanakl olmaması" ifadesi nasıl anlaşılmalıdır?

\section{a. Bir Jus cogens Kuralla Bağlanma İradesinin Açıklanma Biçimi}

Jus cogens kurallarla bağlanma iradesinin açılanma biçimi konusunda söz konusu kurah tanımlayan 1969 Sözleşmesi'nde herhangi bir hüküm ya da açıklama bulunmamaktadır. Diğer yandan, öğretide, bunun ancak çok taraflı antlaşmalarla söz konusu olabileceği şcklindeki görüşün yanı sıra özellikle bu nitelikli antlaşmaların azlığından yola çıkan çoğunluk ise yapulagelişin bu konuda daha elverişli olduğunu belirtmektedir. Buna göre, devletlerin çoğunluğunun hukuk gereği olduğu inancıyla yaptıklan uygulamalarının itirazcı olmayan devletler için de bağlayıcı olması sonucunu doğuran yapılagelişin, oluşum süreci bakımından benzediği jus cogens kurallara zemin hazırlaması uygulamada daha çok karşılaşılabilecek bir durum oluşturmaktadır.

Aslında, "devletlerin uluslararası topluluğunun bütününce kabul edilme" sonucunu doğuracak uluslararası hukukun bütün biçimsel/maddi kaynaklarının bu anlamda yeterli olacağı açıktr. Nitekim, temel amaç ilgili kuralın gerisinde yatan değerin uluslararası toplumun genel bir değerinin olduğunun kabul edilmesi anlamına gelecek şekilde bu niteliğin devletlerin bütününce kabul edilmesi olduğuna göre, bu amaca hizmet edecek antlaşma, yapılagelis ve hatta hukukun genel ilkelerinin bir jus cogens kural oluşumunda biçimsel görevi yerine getirmesinin hiçbir sakıncası olmasa gerektir. Kaldı ki, Sözleşme de bu konuda herhangi bir sınurlamaya gitmemiştir. Elverişlilik konusuna gelince, bu boyutta antlaşmaların nadiren gerçckleştiği anmsatılarak yapılagelişin antlaşmaya göre daha elverişli olduğu belirtilmektedir (AKEHURST, 1978: 47). Diğer yandan, sayları her geçen gün artan ve yasa antlaşma olarak adlandırılan çoktaraflı uluslararası sözleşmelerin de bu açıdan önemli etkisi olabileceği açktır. ${ }^{35}$

\section{b. "Devletlerin Uluslararası Topluluğunun Bütününce Kabul Edilme"}

1969 Sözleşmesi'ne göre, bir jus cogens kuralın oluşması için, "devletlerin uluslararası topluluğunun bütününce (by the international commumity of States as

35 Uluslararası Hukuk Komisyonu da, jus cogens kuralların değişebilirliği bağlamında yaptığı yorumunda, çoktaraflı uluslararası sözleşmelerin bu açıdan önemli bir arạ̧ olacağına dikkat ఢekmiştir (UN, 1971: 68). 
a whole)," kabul edilme ve tanunma ${ }^{36}$ gerekmektedir. Ifadenin Ingilizce yazımından da anlaşıldığı gibi, burada, bütün devletlerin (örneğin, by all States) kabulü aranmamaktadır. Vurgulanan nokta, devletlerin oluşturduğu topluluğun bir bütün olarak kabulüdür. Açıktır ki, burada, devletlerin tek tek iradeleri ikinci plana atlmakta ve yine devletlerden oluşan bütüne atuf yapılmaktadır. Hemen belirtmek gerekir ki, "devletlerin uluslararası topluluğu" da devletlerden oluşmakta ve bu bağlamda devletlerin iradesi hala temel dayanak noktası olmaktadır. Bir başka ifadeyle, devletlerin iradesi devre dışı bırakulmamaktadır. Ne var $\mathrm{ki}$, vurgu bütüne kaydırılarak, tek tek iradelerin bütün içindeki etkisi de bir anlamda sınurlanmaktadır. Tabii ki, tek şartla: "Bütün"ün bütün olma özelliğini bozmayacak ölçekte olma. Nitekim, münferit iradelerin, bütünün varlığın ve niteliğini etkileyecek boyutta olması, "bütün"ün "bütün" olmaması ve hatta belirli bir noktadan sonra başka (yeni) bir "bütün"ün söz konusu olması anlamına gelecektir. Bu ise, münferit iradelerin genel eğilimin oluşmasın engelleyecek şckilde farklılaşmış (heterojen) olduğu ya da yeni bir homojen tutumun oluştuğu durumlara işaret edecektir. ${ }^{37}$

Bu bağlamda yanıtlanması gereken bir diğer soru da, yapılageliş kurallarda olduğu gibi jus cogens kurallarda da sürekli itirazcı olan devletlerin bu kurallarla bağlanmama şansına sahip olup olmadıklarıdır. Bilindiği gibi, doktrinde yaygın bir kabul gören ve UAD'nin de Ingiltere-Norvę̧ Balıķ̧llk Davası'nda dile getirdiği sürekli itirazc kavramına göre, en baştan yani bir yapılageliş kuralın oluşmaya başlamasından itibaren sürekli, kesintisiz ve açık bir şckilde o kuralla bağlanmayacağın açıklayan devletler, sessiz kalarak ya da etkin uygulama ve açıklamalanyla taraf olan devletlerin tersine, söz konusu yapılageliş kuralıyla bağlı olmayacaklardır. Işte bu durumun jus cogens kurallar için de söz konusu olup olamayacağı gündeme gelmiştir. Açıktır ki, çalışma boyunca vurgulanmaya çalışıldığı gibi, jus cogens kuralların temel amacı,

361986 Viyana Sözleşmesi imzalanmadan önce tasarılar üzerinde yapılan görüşmelerde, Yunanistan, Ispanya ve Finlandiya, Konferansa bir öneri sunmuşlar ve "uluslararası topluluğun bütünü"ne atıf yapılmasını ve metinde yer alacak olan "devletlerin" ifadesinin çıkarılmasını önermişlerdir. Ne var ki, ৎ̧oğunluğun bu tür kurallan kabul etmeye ve tanımaya (accept and recognise) çağrılanların devletler olduğunu dile getirmiş ve öneri reddedilmiştir. Bu konuya dikkat çeken kaynak için bkz. (RAGAZZI, 1997: 54-55). Diğer yandan, "tanınma ve kabul edilme" ifadesi de, UAD Statüsünün 38. maddesinde ifadesini bulan uluslararası hukukun kaynaklarının tümünü kapsama amacıyla özellikle tercih edilmiştir. Bkz. (RAGAZZI, 1997: 52-53).

37 Nitekim, UAD, Nicaragu Davasinda (paragraf 186), yapılageliş hukuku konusunda yaptığı değerlendirmede, opinio juris'in mevcut olduğu durumlar için, devletlerin uygulamalarının hepsinin kesinkes aynı yönde olmasının gerekmediğini, önemli olanın genellik olduğunu, ve uygun olmayan davranşlann da yeni bir kuralın tanındığının işaretleri olarak değil de mevcut kuralın ihlali olarak değerlendirilmesinin gerektiğini belirtmiştir. Bu değerlendirmeyi jus cogens kuralların "devletlerin uluslararası topluluğunun bütününce kabul edilme"si bağlaminda aynen benimsemek yanlıs olmasa gerektir. 
uluslararası toplumun temel ve öncelikli değerlerini devletlere karşı korumaktar. Bu nedenle, amaa zaten temel konularda devletlerin çelişen uygulamaların engellemek olan kuralların, selişen uygulamalara izin vermesi ya da izin verir şekilde yorumlanması olanaklı değildir. Kısacası, bir kural ya jus cogens kuraldır ve bu nedene hiçbir devlet sürekli itirazcılık ya da başka bir gerekçeyle ondan bağışık olamayacaktır, ya da itirazlar bir jus cogens kuralın oluşmasını engelleyecek seviyededir ve bu nedenle de ortada bir jus cogens kural olmayacağından bir jus cogens kurala karşı itirazdan bahsetmek de söz konusu değildir.

Sonuç olarak, herhangi bir değerin uluslararası toplumun temel ilke ya da kuralı olduğu konusunda uluslararası toplulukta çok yaygın bir kanaat olması ve aykın seslerin topluluğun bütünsel yapısı içerisinde hiç etki doğurmaması durumlarının "devletlerin uluslararası topluluğunun bütünü" ifadesini karşıladığı söylenebilir. Görüldüğü gibi, bir değerin jus cogens kural olarak kabul edilmesi için bütün devletlerin iradesinin bu yönde olması gibi bir koşul bulunmamaktadir. Bu nedenle, devletlerin niceliksek ya da niteliksel miktan konusunda, önemli olan toplumun o kural bağlamında bütünsel bir görüntü çizmesi olduğundan, bu koşulu sağlayacak şekilde olanaklı olduğunca çok sayıda ve farklı bileşenleri temsil edecek nitelikte devletin bu yönde iradesinin gerekli olduğu söylenebilir. Aynca, bu tür konularda önemli olanun ciddi ve önemli ölçüde destek bulan bir itiraz gelmemesi olduğu anumsandığında, bir değerin jus cogens kural niteliğini kazanup kazanmadığınun saptanması sırasında yapılan itirazların ve bu itirazların kapsam ve etkisinin de göz önünde bulundurulması gerekmektedir.

\section{c. Bir Jus cogens Kuralla Bağlanma Iradesinin Niteliģi}

Jus cogens kurallarla ilgili yanitlanması gereken üçüncü soru ise, olası bir jus cogens kuralın getirdiği düzenlemeyle bağlanma iradesinin niteliğiyle ilgilidir. Açıtır $\mathrm{ki}$, bir jus cogens kurals jus cogens kural yapan, bu kuralın içeriğine, yani getirdiği düzenlemeye bağh olma iradesi değildir. Daha doğrusu, jus cogens kuralların ayırt edici özelliği bu değildir. Zira, bu durum, "sıradan" her hukuk kuralı için de geçerlidir. Bir jus cogens kuralı "sıradan" kurallardan ayıran temel özellik, kendisine aykın hiçbir kuralın yarathlamayacağı ve kendisinden sapılamayacağ 1 yönündeki inançtur. ${ }^{38}$ Bireyler, toplumun temel değerlerini düzenlediğini kabul ettikleri bu tür kurallara aykırı işlem yapmamayı ve bu kurallardan ayrimamayı kabul etmektedirler. Bunun tek

38 Jus cogens kuralların bazı açılardan benzedikleri yapulageliş kurallardan en önemli farkı, bu nitelikleridir. Hatta, bu nedenke, jus cogens kuralların niteliğine yönelik bu inanє, özel bir opinio juris çeşidi olarak nitelenmiştir. Bkz. (RAGAZZI, 1997: 53). 
istisnası önceki bir jus cogens kurala aykın yeni bir jus cogens kuralın yaratılmasıdır ki bu hemen aşağıda incelenecektir. Kısaca, bir jus cogens kuralın temel ayırt edici özelliği, içerdiği düzenleme değil kendisine atfedilen niteliktir.

\section{d. "Kendinden Sapmanın Olanaklı Olmaması"}

Sözleşme'nin getirdiği düzenlemede, devletlerin jus cogens kurallardan sapmasının olanaklı olmadığı belirtilmektedir. Bir başka ifadeyle, devletlerin jus cogens niteliğe sahip bir kurala aykın bir düzenleme yapması olanaklı değildir. Jus cogens kuralların bu özelliği konusunda üzerinde durulması gereken birkaç nokta bulunmaktadır.

Birincisi, her ne kadar "sapmanun olanaklı olmadığı" şeklindeki ifade jus cogens kuralların otomatik olarak etki doğuran ve devletlerin kendisine aykun bir işlem yapma serbestisini mutlak olarak yasaklayan kurallar olduğu izlenimi yaratsa da, bunun gerçekte böyle olmadı̆̆ ạ̧ktar. Nitekim, bir jus cogen- kurala aykırı bir antlaşma yapılması durumunda olduğu gibi, söz konusu işlem otomatik olarak geçersiz olmamaktadır. Geçersizliğin ya da sona ermenin saptanması ancak taraflardan birisi tarafından başlatılabilen bir süreç sonrasında gerçekleşebilmektedir. ${ }^{39}$ Bu nedenle, bu ifadenin sapmay "engelleyen" değil "yasaklayan" bir anlama sahip olduğunu vurgulamak yerinde olacaktır. Kısacası, her hukuk kuralında olduğu gibi jus cogens kurallarda da sonucu ve sorumluluğu göze alan herkesin bu kurallan çiğneyebileceği açıktr. Tekrar vurgulamak gerekirse, jus cogens kuralların diğer "sıradan" kurallardan temel farkı, çatışan düzenlemelerin çatş̧ma anından itibaren batıl sayılması ve sürecin sadece bu geçersizlik durumunun saptanmasından ibaret olmasıdır. "Siradan" kurallarda ise, saptanacak olan ilgili düzenlemenin geçersiz olup olmadığıdır.

Ikincisi, bir sapmanın olup olmadığını saptamak için neye bakılacağıdır. Bir antlaşmanun bir jus cogens kuraldan sapan hükümler içermediğinin saptanması konusunda yanıtlanması gereken temel bir soru vardır. Söz konusu antlaşmanın sadece içeriğine ya da uygulanmasına $\mathrm{mi}$ bakulacaktır yoksa birbirinden ayrılamayacaklan savınun bir sonucu olarak ikisine birden mi? Bu tartı̧̧ma, 1969 Sözleşmesi'nin hazırlanması sırasında Uluslararası Hukuk Komisyonu'nda da gündeme gelmiş ve raportörlerden Lauterpacht, yaptŭ̆ öneride, antlaşmanin amaçyla uygulanmasınun bir bütün oluşturduğunu belirterek temel ölçütü antlaşmanın performansınun bir jus cogens kurala aykırı olup olmadiğı seklinde formüle etmiştir. Bir diğer raportör olan Fitzmaurice, uygulamadan hiç bahsetmeyerek tek ölçütün antlaşmanın amaa olduğunu belirtmiştir. Diğer raportör Waldock ise, uygulama veya amaçtan birisinin ya da 
ikisinin birden bu bağlamda dikkate alınması gerektiğini bildirmiştir (ROZAKIS, 1997: 98-99). Komisyon ise, Waldock'un sunduğu son taslak maddede yer alan "yürütülmesi" ifadesini çkarmıştur. Her ne kadar "yürütülmesi" ifadesinin çkarılması sadece amaca önem verildiğinin bir göstergesi olarak değcrlendirilse de (ROZAKIS, 1997: 93), açıktur ki, Komisyon, bir ayruma gitmemeyi ve hangi sekilde olursa olsun bir jus cogens kurala aykin olan sonuçla ilgilenmeyi tercih etmiştir. Nitekim, eğer savunulduğu gibi sadece amaca önem verilseydi, bunun ilgili maddede böyle ifade edilmesi gerekirdi. Ne var ki, Sözleşme, "öncelikli bir kuralla çatşan bir antlaşma geçersizdir," diyerek tercihi ortaya koymuş, "antlaşma"yı içeriği ve uygulanmasıyla bir bütün olarak değerlendirmiştir. Içeriğiyle uygulanması farklı olan antlaşmalar için söz konusu olabilecek bu tür durumlarda jus cogens kurala aykırıliğın nereden kaynaklanırsa kaynaklansın saptanması ve duruma uygun olan önlemin alınması yerinde olacaktr.

Aslında, Sözleşme'nin bu düzenlemesi, uygulamadan kaynaklanan sorunların yarattı̆̆ı riski de büyük ölçüde gidermiştir. Nitekim, amaç, içerik ya da konu bir jus cogens kurala aykun olmamakla birlikte, uygulamanin bir aykırnlık teşkil etmesi her zaman için olasıdır. Birkaç devletin ${ }^{40}$ aralarında anlaşarak uluslararası hukukun meşru kabul ettiği bir konu ve içerikte bir antlaşma imzalaması ama bu antlaşmayı bir jus cogens kuralı ihlal eder şekilde uygulamaları buna en iyi örnek olsa gerektir. Diğer yandan, uygulamanın kendi özelliklerinden kaynaklanan kimi gelişmelerin taraf devletleri hiç düşünmedikleri bir konuma sürüklemesi olasılığı da söz konusu olabilecektir. Sonuç olarak, "öncelikli bir kuralla çatı̧̧an bir antlaşmanın geçersiz olması"ndan bahsedilmesi ve amaç ve uygulama farkına gidilmemesi, jus cogens kuralın uygulanmasının izlenmesi açısından yerinde bir düzenleme olmuştur.

\section{3. "Ancak Aynı Nitelikli Bir Kuralla Değiştirilebilme"}

Jus cogens kuralların üçüncü temel özelliği ise, ancak ayn nitelikteki bir başka kuralca değiştirilebilmeleridir. Buna göre, kendisine aykını her türlü gelişmeyi geçersiz kılan ve hukuk dışına iten jus cogens kurallar da, diğer "suradan" kurallar gibi değiştirilebilirler. Ancak, bunun koşulları iyice ağırlaştırılmıs ve yetki ancak yeni bir jus cogens kurala tanınmıştır. Bir başka ifadeyle, jus cogens kurallar da değiştirilebilirler ama bu diğer "sıradan" kurallar gibi örneğin bir grup taraf devletin aralarında anlaşmasıyla olamaz. Değişiklik için "devletlerin uluslararası topluluğunun bütününce" benimsenen yeni ve aykırı bir jus cogens kuralın söz konusu olması gerekmektedir. Bunun uygulamada nasıl olanaklı olacağı tartı̧malıdır. Nitekim, bir jus cogens kural, 
kendine aykırı gelişmelere otomatik olarak hukuk dışına itmektedir. Hukuk dışına itildiği için bir değeri de olmayan olguların yeni bir jus cogens oluşturması da olanaksız olacaktur. Diğer yandan, örneğin "devletlerin uluslararası topluluğunun bütünün" toplanarak çok taraflı bir antlaşma yapması ve bu yolla bir jus cogens kural yerine yeni bir jus cogens kural benimsemesi en azından teoride olanaklı görünmektedir. Bu arada, uluslararası toplumun yapısında çok köklü bir değişiklik olması durumunda da -tabii öncelikli kuralların gerekliliğgi anlayışı sürmek koşuluyla- öncekilerle çatışan ve tamamen yeni jus cogens kuralların oluşması olanakh olabilecektir.

Bu nedenle, mevcut bir jus cogens kurala aykun yeni bir jus cogens kuralın oluşması neredeyse olanaksız olacağından, jus cogens kuralların ancak içerik itibariyle kimi evrimsel değişmelere daha elverişli olduğu açıktur. Daha açık bir ifadeyle, bir kere yaratildiktan sonra değişmesi neredeyse olanaksız olan jus cogens kurallann içeriği, uluslararası toplumun gelişmesine uygun olarak şekillenebilecektir. Örneğin, "bugün eğer jus cogens kurallar varsa buna en iyi örnek uluslararası ilişkilerde kuvvet kullanmanun yasaklanmasıdır," görüşünden yola çlkarak, BM Antlaşması'nun 2/4. maddesinden kaynaklanan kuvvet kullanma yasağına daha sonra çeşitli gelişmelerle genişlediği ileri sürülmektedir. Diğer yandan, insan hakları ve hatta uluslararası çevre hukukunda yaşanan gelişmelere koşut olarak bu alanlarda da yeni şekillenme eğilimlerinin olduğu açıktır.

$\mathrm{Bu}$ arada, bir jus cogens kuralın sadece bu niteliğinin sona ermesinin olanaklı olup olmadığına da kısaca değinmek yerinde olacaktır. Kuşkusuz, bir jus cogens kural da, uluslararası toplumun o konudaki değerlerinin ve "devletlerin uluslararası topluluğunun bütününün" iradesinin değişmesi sonucu yerini yeni bir jus cogens kurala burakmaksızın ortadan kalkabilecektir. Uluslararası toplumun yapısındaki değişmeler kimi değerlerin öncelikli olma niteliğini değiştirebilecektir. Nitekim yeni gelişmeler sonucu daha önce öncelikli niteliğe sahip olan bir kural "sıradan" bir kural haline dönebilecek ve bu durumda da ancak bu yeni niteliğiyle bağlanmak isteyen devletler için "sıradan" bir kural olarak geçerliliğini sürdürecektir. Hatta, bir jus cogens kuralın içerdiği hükmün hiçbir hukuksal değer taşımayacak şekilde tamamen ortadan kalkması da olanaklıdır.

Burada hemen belirtmek gerekir ki, jus cogens üzerine yapılan en kapsamlı çalışmalardan olan kitabında Rozakis, bir antlaşma hükmüyle yaratılmış olan bir jus cogens kuralın söz konusu antlaşmanun sona erdirilmesiyle de değiştirilebileceğini ve hatta sona erebileceğini ileri sürmektedir (ROZAKIS, 1997: 93). Ne var ki, bu yaklaşım tartışmalıdır. Nitckim, tıpkı yapılageliş nitelikli kurallarda olduğu gibi jus cogens kuralların da bir kere yaratildıktan sonra onu yaratan biçimsel işlemden bağımsız olarak varlık kazandiğı açıktır. Daha açık bir deyişle, jus cogens nitelikli bir kuralın bir antlaşmayla yaratılması 
durumunda, taraflan jus cogens niteliğiyle bağlayan artık söz konusu antlaşmanun hükmü değildir; jus cogens kural, ilgili hükümden ve o hükmü içeren antlaşmadan bağımsız olarak ayrn bir varlığa sahiptir. Bu nedenle, jus cogens kuralın değiştirilmesi ya da ortadan kaldırılması için ilgili iradelerin bu kuralı içeren antlaşmaya değil jus cogens kuralın kendisine yönelmesi gerekmektedir. Tamamen bir jus cogens kural yaratmaya yönelik antlaşmalar durumunda ise durum daha da karmaşıktur. Ne var ki, böyle bir antlaşmayı değiştirirken ya da sona erdirirken o antlaşmayla yaratılan jus cogens kuralın bu niteliğine ve geleceğine ilişkin bir açklamanin ya da düzenlemenin yapılmasının sorunu çözeceği ą̧ktur. Nitekim, böylece, uluslararası toplumun bu kurala dayanak olan temel değerinin yani "devletlerin uluslararası topluluğunun bütününün" iradesinin değişip değişmediği açıkça anlaşılmıs olacaktur.

Son olarak belirtmek gerekir $\mathrm{ki}$, mevcut bir jus cogens kurala aykur islemin ya da eylemin uluslararası toplumdan bir tepki almaması ve bu aykırı işlem ya da eylem üzerine yeni hukuksal işlem ya da eylemler inşa edilmesi durumlarında da söz konusu kuralın artak jus cogens niteliğini devam ettiremeyeceği açuktır. Bu durumda, yeni bir jus cogens kuralın eski bir jus cogens kuralı değiştirmesinden söz etmek mantiksal olarak yanlış olacaktır. Zira, eski kural, jus cogens olma niteliğini yitirmiştir (ROZAKIS, 1997: 89, 92). Her durumda, mevcut bir jus cogens kurala aykin uygulamaların ciddi bir itirazla karşılaşmaması ve hatta bu uygulamanın destek bulması, yeni bir jus cogens kuralın oluşması sürecini de başlatabilecektir.

\section{Sözleşme'ye Göre Bir Jus cogens Kuralla Çatışan Antlaşmanın Geçersizlligin veya Sona Erdiğinin Saptanması Yöntemleri}

1969 Sözleşmesi'nin 53 ve 64 . maddeleriyle bir jus cogens kuralla çatşan antlaşmanun çatışma anından itibaren geçersiz (batıl) olacağı belirtilmesine rağmen, geçersizliğin saptanması kendiliğinden başlayan ya da gerçekleşen bir yöntem olarak öngörülmemiştir. Bu durumdaki antlaşmaların geçersizliğinin saptanmasıyla sonuçlanacak sürecin harekete geçirilebilmesi yetkisi sadece taraflara verilmiştir. Buna göre, aşağıda belirtilecek olan kimi farklılıklar olmakla birlikte, jus cogens kuralla çatı̧̧an bir antlaşmanın geçersizliğinin ya da sona erdiğinin saptanması, diğer geçersizlik ve sona erme durumlanyla ayn süreç sonunda olanaklı olmaktadır. ${ }^{41}$ Nitekim, Sözleşme'nin 46-52. maddelerinde taraf devletlerin çkarların koruma amaayla getirilen

41 Yukanda da belirtildiği gibi, jus cogens kurallarla ilgili durumlarda zaten çatş̧mayla birlikte söz konusu olan geçersizlik saptanurken, diğer dunumlarda öncelikle ilgili düzenlemenin geşersiz olup olmadığına karar verilmektedir. 
düzenlemelerle, seşitli etkenlerin zorlamasıyla ve tam rızası olmadan bir antlaşmayla bağlanmak durumunda kalan devletlerin, söz konusu antlaşmayı geçersiz kllma ya da sona erdirme sürecini başlatarak zarar gören bireysel çkarların koruyabilmesinin yolu açlmaktadır. Devletlerin ancak tam rizalariyla taraf olduklan antlaşmalarla bağlanabileceği temel kuralından yola çkan Sözleşme, devletlerin bireysel çkarlannun zarar görmesinin söz konusu olduğu durumlarda ilgili sürecin başlatılması yetkisini sadece taraflara vererek bu konuda kendi içerisinde tutarł bir düzenleme yapmuştur.

Diğer yandan, temel amac tarafların değil de $\mathrm{d}^{42}$ uluslararası toplumun genel ģkarlarının korunması olan jus cogens kurallarla çatışan antlaşmaların geçersizliğinin veya sona erdiğinin saptanacağı sürecinin başlatılmasının da yine sadece taraflara burakılması dikkat çekicidir. Düzenlemenin bu haliyle jus cogens kurallarun kabul edilmesiyle amaçlandığı gibi uluslararası toplumun temel çıarların korumaya tatmin edici bir şekilde hizmet ettiğini söylemek zordur.

Antlaşmaların geçersizliği ve sona erdirilmesi için öngörülen sürece gelince, taraf devletler, jus cogens kurallarla çatş̧ma gerekçesi de dahil tüm durumlarda, geçersizlik ya da sona erdirme isteklerini ve önerdikleri önlemleri gerekçeleriyle birlikte diğer taraflara [yazılı olarak] bildirmekte (madde 65/1) ve acil durumlar hariç üç aylik bir süre geçmesine rağmen bir itiraz gelmemişse 67 . maddede öngörülen yönteme ${ }^{43}$ uygun olarak önerdiği önlemleri uygulayabilmektedir (madde 65/2). ${ }^{44}$ Diğer tarafın itiraz etmesi durumunda ise, taraflar, BM Antlaşması'nun 33. maddesinde belirtilen araçlarla (madde 65/3) 15 ay içerisinde (madde 66) bir çözüm bulmaya çalışacaktır. ${ }^{46}$

$42 \mathrm{Bu}$ arada, hemen belirtmek gerekir ki, "taraflann çıkarların korumaya yönelik" ifadesini mutlak anlamda almamak gerekmektedir. Cünkü, özellikle kuvvet kullanma tehdidiyle antlaşma imzalattırılması söz konusu olduğunda durumun sadece ilgili tarafın çıłan açısından önem taşımadığı açıktır. Bu tür bir antlaşmanın hem biçimsel olarak yürürlüğe girmesi hem de yapılıs şekli uluslararası toplumun genel çıkarlan açısından da sakıncalı olsa gerektir. Nitekim, böyle bir durum, BM sisteminin temel ilkelerden uluslararası bans ve güvenliğin korunmasına aykın olması nedeniyle her durumda uluslararası toplumun genel şkarlannı da ilgilendirecektir. Bu ise, kuvvet kullanma tehdidiyle imzalattırlan antlaşmalanı geçersiz kılınmasının ilgili tarafın çıarının yanı sıra uluslararası toplumun temel şıkarları açısından da önem taşıdığın göstermektedir. Kısacası, burada kullanılan "taraflann şıkarını korumaya yönelik olma" ifadesi, mutlak değil göreli bir anlam taşımaktadır.

43 Yazılı olarak yapılan bildirimin ayrıca ya o devleti temsil etmeye kendiliğinden yetkili kişilerden biri ya da yetki belgesini göstermek kaydıyla özel olarak yetkilendirilmiş bir temsilci tarafundan imzalanması gerekmektedir (madde 67).

44 Görüldüğü gibi, geçersizlik ya da sona erdirme isteğinin söz konusu olabileceği tüm durumlarda ilgili sürecin başlatılması yetkisi sadece taraf devletlere verilmektedir.

45 Görüşme; soruşturma; ara bulma; uzlaşma; tahkim; ve yargı.

46 Taraf devletlerin önemli bir kssmının öngördüğü zorunlu çözüm yolu nedeniyle 66. maddeye çekince koyması, jus cogens kurallarla ilgili önemli bir eksikliktir. Bu noktadan yola çıan Ragazzi, tüm sorunları çözecek en iyi yaklaşımın, jus cogens kurallan çok açık ve net bir şekilde tanımlama çabası olacağını belirtmektedir. Bkz. (ROZAKIS, 1997: 49). 
Nihayet, taraflarin BM Antlaşmasi'nun 33. maddesinde önerilen yöntemlerle de bir çözüm bulamamalan durumunda, bir jus cogens kurala aykurulk gerekçesiyle diğer yedi gerekçenin (46-52. maddeler) söz konusu olduğu durumlar arasında bir ayruma gidilmekte ve diğer yedi durum için BM Genel Sekreteri'nden istekte bulunmakla başlayan farklı bir süreç öngörülürken (madde 66/b ve Ek) ilk durum için konunun Uluslararası Adalet Divanı (UAD)'na götürülmesinin yolu açlmaktadır (madde 66/a). Buna göre, eğer taraflar uzlaşmazlığı hakeme götürme konusunda da anlaşmamışlarsa, taraflardan herhangi birisi 53 ve 64 . maddelerin uygulanmasi veya yorumu konusundaki uyuşmazlı̆̆ı yazılı bir dilekçeyle UAD'ye götürebilecektir (madde $66 / a)$.

Görüldüğü gibi, devletlerin uluslararası toplumun öncelikli/üstün kura!'.uıyla çatışan işlemler yapmasın engellemek için kabul edilen jus cogens kurallara uyulmasınun denetlenmesi, yine uluslararası toplumu temsil ettiği varsayllan UAD'ye ancak yaklaşık 15 aylık bir süreç sonrasında burakılmaktadır. Daha da önemlisi, tekrar vurgulamak gerekirse, konunun UAD'ye sunulmasıyla sonuçlanabilecek sürecin başlatılması yetkisi de sadece taraf devletlere bırakılmıştur. Hem bağlanılacak kurallan belirleyen hem de bu yolla yaratılan kurallara uyacağı varsayılan sujelerin ayn olması nedeniyle ciddi tartışmalara konu olan ve hatta bu nedenle varlığı bile tartışlan uluslararası hukuk, diğer yandan, üstün/öncelikli kurallarına uyulup uyulmadığın denetleme sürecinin başlatılabilmesini de yine taraf devletlere bırakmaktadır. Kuşkusuz, taraflardan birisinin tam mzası dışında ya da konusunun meşruluğu hakkında ciddi kuşkuları olmasına rağmen imzaladığı antlaşmalar söz konusu olduğunda, ilgili devlete 1969 Sözleşmesi'nde öngörülen yöntemlere uygun olarak yaptiğı girişimler sonrasında konuyu UAD'ye götürme olanağı sağlanması amaca hizmet eder niteliktedir. Ne var ki, iki ya da daha fazla devletin aralarında anlaşarak mevcut bir jus cogens kurala aykın hüküm(ler) içeren bir antlaşma imzalaması durumunda, tehdit edilen uluslararası toplumun genel değerlerinin nasıl korunacağı kuşkuludur. Tarafların hepsi de antlaşmanın içeriğinden memnun olacağına ve hiçbiri antlaşmanun geçersizliğini ya da sona erdirilmesini istemeyeceğine göre, uluslararası toplumun üstün çkarlarını ihlal eden bu antlaşmanın geçersizliğini saptamak (ve hatta uygulanmasın durdurmak) olanaklı olmayacaktır. Bu ise, jus cogens kuralların etkin bir sckilde uygulanmasının olanaksız olduğu bir duruma işaret etmektedir.

Aslında, jus cogens kurallarnn kimi devletlerce ihlal edilmesinin önüne geçmek amaçyla geçersizliği veya sona ermeyi saptama sürecini başlatmak yetkisinin tüm devletlere verilmesinin gerekli olduğu şeklinde görüşlere de rastlanmaktadır (GAJA, 1981: 283). Jus cogens kuralların etkinliğini önemli ölçüde artırabilecek bu tip bir düzenleme, yetkinin ilgili antlaşmaya taraf olmayan devletlerce kötüye kullanılması endişesinin dile getirilmesi, 
antlaşmalann güvenirliği ve istikran ilkesi ve devletlerin bu yolu antlaşmalardan doğan uluslararası sorumluluklarından kaçma bahanesi olarak kullanabilecekleri kayglanyla kabul görmemiştir (SCHWELB, 1967: 962-963; RAGAZZI, 1997: 48). Gerçekten de, antlàşmaların bir jus cogens kurala aykunlık savıyla geçersiz kulınması sürecinin başlatlması yetkisinin taraf olmayan devletlere de verilmesi, her zaman için kötüye kullanmaya açk olan bir durumdur. Ne var ki, bir hakkı ya da yetkiyi "kötüye kullanmanin önüne geçmek" ile o hakkı ya da yetkiyi "kullanmanın önüne geçmek" çok farklı şeylerdir. Eğer bir hakkın ya da yetkinin kullanulması isteniyorsa ve gerekli olduğu açıksa, önemli olan, onun kötüye kullanimasın engelleyecek şekilde düzenlemeler yapmaktur. Nitekim, eğer jus cogens kurallarla uluslararası toplumun temel ve öncelikli kuralları korunacaksa, bunu koruma işi de uluslararası topluma bırakılmahdır. Uluslararası toplumu oluşturan devletlerin her birinin (tabii, bu arada taraf devletlerin) ya da uluslararası toplumu temsil edecek bir örgütün ve belki de bir yargı organunun bu yetkiyle donatıln:ası bu bağlamda akla gelebilecektir. Diğer yandan, özcllikle devletlere verilmesi durumunda yetkinin kötüye kullanulmasının önüne geçecek düzenlemeler yapılması da gerekecektir. Böylece, bir yandan uluslararası toplumun temel değerlerini koruma yetkisi sadece bu temel kuralları çiğnemiş olabilecek devletlere bırakılmamış olacak, diğer yandan da antlaşmaların güvenirliği ve istikran her isteyenin sorgulayamayacağı bir düzene kavuşturulmuş olacaktur. Jus cogens kurallan doğuran anlayışın temel hedefi de bu olsa gerektir. Bu arada, jus cogens kuralların var olması gibi kötüye kullanılma riskinden uzak bir şekilde uygulanmasının da uluslararası toplumun örgütlenme düzeyiyle doğrudan bağlantılı olduğu açıktr. Bu kurallar, ancak hukukun genel olarak etkin olduğu bir toplumda amaca tam hizmet eder şekilde uygulanabilecektir. Yukarıda da belirtildiği gibi, hukuku toplumda etkin kulmanun en önemli yöntemlerinden birisi, yargı organun gü guclendirilmesidir. $\mathrm{Bu}$ nedenle, uluslararası toplumun yargı organ olarak kabul edebileceğimiz UAD'nin yapısının, yetkilerinin ve etkisinin güçlendirilmesi, uluslararası toplum için büyük önem taşımaktadır.

Sözleşme'nin 53 ve 64. maddelerinden açıkça anlaşıldığı gibi, bir kuralın jus cogens kural olmasının en önemli sonucu, kendisiyle çatı̧an antlaşmayı geçersiz kılmasıdır. Bu konudaki temel ilke, jus cogens kuralların, kendisiyle çatışan antlaşmaları çatışma anından itibaren geçersiz kılmasıdır. Buna göre, hazırlandığı anda geçerli olan bir jus cogens kurala aykırı hükümler içeren tüm antlaşmalar ölü doğacak ve hiçbir hüküm doğurmayacaktır (madde 53). Kuşkusuz, bu çatışmanın tespit edilmesi ve gerekli çözümün alınması yukanda anlahlmaya çalışılan süres sonrasında olanaklı olabilecektir. Ne var ki, geçersizlik an çatışmanın tespit edildiği değil çatışmanın gerçekleştiği andan başlayarak etki doğuracaktır. 
Hazırlandiğı anda mevcut bir jus cogens kurala aykın düzenleme içermeyen antlaşmalarnn kimi hükümlerinin daha sonra ortaya çkan yeni bir jus cogens kuralla çaş̧ması durumunda ise, yine temel ilke gereği, antlaşma geçersiz hale gelecek ve sona erecektir ${ }^{47}$ (madde 64). Burada, yeni ortaya ģkan bir jus cogens kurala aykun bir hükmü içeren antlaşmanun kimi koşullara göre tümünün ya da sadece ilgili hükmünün geçersiz hale geleceği belirtilmektedir. Buna göre, jus cogens kurala aykın hükmün onu içeren antlaşmanun temel maddesi olması ve içerdiği düzenlemenin antlaşmanun bütününü etkiler nitelikte olması durumunda antlaşmanun tümünün sona ermesi gerekecektir. Diğer yandan, ilgili maddenin antlaşmanin herhangi bir maddesi niteliğinde olduğu ve antlaşmanun bütününe ya da geneline bir etkisinin olmadiğı durumlarda ise sadece o maddenin sona erdirilmesinin yeterli olacağ belirtilmektedir (SCHWELB, 1967: 971-972).

\section{Sonuç} olanaklıdır.

Yapılan bu incelemelerden sonra, aşağıdaki sonuçlara ulaşmak

1. Her toplumda olduğu gibi uluslararası toplumda da toplumun düzenini sağlayan bir hukuk düzeni (uluslararası hukuk) vardur.

2. Uluslararası hukuk, her ne kadar henüz uygulamadan kaynaklanan kimi sorunlar yaşansa da, tüm devletleri bağlamaktadır ve uluslararası hukuka uymayan devletlerin hukuksal sorumluluklan doğmaktadır. Bu arada, yapılageliş kurallarda karşımıza çkan sürekli itirazc kavramı, jus cogens kurallar için söz konusu değildir. Çünkü, sürekli itirazcılık, jus cogens kurallarnn varlık sebebini ortadan kalduracak ve o temel değerlerle çelişen davranışların hukuk đışına itilmesini olanaksız kılacaktır.

3. Her hukuk düzeninde olduğu gibi, uluslararası hukukta da, o toplumun temel değerlerini yansıtan ve sujelere karşı korunan temel kural ve ilkeler vardır. Ulusal hukuk düzenlerinde "kamu düzeni" adıyla korunan bu kural ve ilkelerin uluslararası hukuk düzeninde korunması için gündeme gelen öncelikli/üstün kurallar, jus cogens kurallar olarak tanımlanmaktadır. 1969 Viyana Antlaşmalar Hukuku Sözleşmesi'yle pozitif hukuka kesin olarak aktarılan jus cogens kurallar, her ne kadar bu kurallar henüz içtihatta somut bir şekilde örneklenmemişse de, doktrinde çok yaygın bir şekilde kabul görmüştür. Kısacası, başlangıçta doğal hukukçuların istekleri olarak görünen bu tür kurallarnn mevcudiyeti günümüzde genel kabul görmektedir.

47 Komisyon, ilgili yorumunda, "becomes ooid and terminates" ifadesinin jus cogens kurallann geriye yürümezliğini vurguladı̆̆ın ifade etmiştir (UN, 1971: 68). 
4. Egemen devletlerin iradelerini esas alan uluslararası hukukta kaynak hiyerarşisı olmadığı bu nedenle de uluslararası hukukun üst/öncelikli kurallara elverişli olmadığı görüşü, bu kuralların oluşma sürecini ve şeklini gözden kaçurmaktadır. Jus cogens kurallar, uluslararası toplumun üstün bir otoritesi tarafindan oluşturulmayı gerekli kulmamaktadir. Bu kurallann tek ayırdedici özelliği, uluslararası toplumun ilgili değeri sonucunda kendilerine atfedilen niteliktir. Nasıl ki ulusal hukuklarda yine yasaları yapan kurumlarca hazırlanan Anayasalar, toplumun bütününün iradesini yansitacak ölçekte nitelikli bir çoğunluğun oyuyla kabul ediliyorsa ve anayasalara bu niteliği veren farkh bir kaynakça yapılmalan değil de kendilerine atfedilen nitelikse, jus cogens kurallar da nitelikleri gereği uluslararası toplumun bütününün değerini yansıtacak sekilde olmak koşuluyla yine aynu kaynak tarafından (devletler) oluşturulmaktadir.

5. Amacı uluslararası toplumun temel değerlerini korumak olan jus cogens kurallara uyulmasının sağlanması ve karşı eylemlerin hukuk dışına itilmesi, en az bu kuralların varlığı kadar önemlidir.

6. Diğer yandan, "etkinlik"le "var olma"nun farklı şeyler olduğu açıktır. Her ne kadar getirilen yöntemle jus cogens kuralların etkin bir şekilde uygulanması ciddi engellerle karşı karşıyaysa da, bunun, jus cogens kuralların gerekliliği ve varlığın sorgulamaya neden olmaması gerekmektedir. Kaldı ki, uluslararası toplumun temel dayanak noktası olarak da görülen pacta sunt servanda ilkesinin de bir jus cogens kural olduğunu söylemek yanlış olmasa gerektir.

7. Uluslararası toplumun bugünkü yapısı itibariyle bu kuralların kötüye kullanılabileceği açıktur. Uluslararası toplumun en yaygın şckilde temsil edildiği BM'de bile devletlerin eşitliği ilkesine uyulmaması bu durumun en önemli nedenidir. $\mathrm{Bu}$ nedenle, uluslararası toplumun örgütlenmesinin ve kurumsallaşmasının temel ilke olan eşitlik üzerinden derinleştirilmesi ve özellikle jus cogens gibi temel konularda UAD'ye zorunlu yarg1 yetkisinin verilmesi durumunda, var olan jus cogens kuralların etkin ve kötüye kullanılmaya kapahı bir şekilde uygulanması olanaklı olacaktur.

\section{Kaynakça}

AKEHURST, Michael (1978), A Modem Introduction to Intemational Law (Londra: George AllenEUnwln Ltd., 3. B.).

ALEXIDZE, Levan (1981), "Legal Nature of Jus Cogens," Recueil des Cours, 1981/11: 223-270.

BROWNUE, lan (1990). Principles of Public Intemational Law (Londra: Oxford. 4. B.).

FASTENRATH, Ulrich (1993). "Relative Normativity in Intemational Low." European bumal of Intemaional Law. 4/3: 305.340.

GAJA. Glorgio (1981), "Jus Cogens Beyond the Vienna Convention." Recueil des Cours, 1981/Ill: 271-316. 
PAZARCI, Hüseyin (1977), “Uluslararası Hukukta Jus Cogens Kovramu," Prof. Dr. Bülenl Nuri Esen'e Ammagan (Ankara: AC SBF): 365-379.

RAGAZZ, Maurizio (1997). The Concept of Intemational Obligations and Erga Omnes (Oxford: Clarendon Press).

RAO, V. Negeswar (1974). "Jus Cogens ond the Vlenns Convention on the Low of Treatles." Indian Jumal of Intemational Law. 14/3-4:362-385.

ROZAKIS, Christos L. (1976), The Concepl of Jus cogens in the Law of Trealies (Oxford: North-Holland Publishing Compony).

SCHWARZENBERGER, Georg (1971), Intemational Law and Onder (New York: Proeger Publishers).

SCHWEBB, S. (1967). "Some Aspects of Internotional hus Cogens as Formulated by the Intemational Law Commisston." Anerican Joumal of Intemational Law. 61/4:946-975.

SHAW, Malcolm (1999), Intemational Law (Cambrige: Cambridge University).

TOUUNER. Sevin (1975), Kubns Uyuşmazlığ ve Milletlerarası Hukuk (Istanbul: IO Hukuk Fakültesi).

TUNKIN, Georg (1974). Theory of Intemational Law (Londra: Georg Allen E Unwin Led.) (sev. William E. Butler).

UN (1970). UN Conference on the Law of Trealies, Second Session, Vienna, 9 April-22 May 1969, Official Records, Summany Reconds of the Plenary Meetings and of the Committee of the Whole (UN. New York).

UN (1971), UN Conference on the Law of Trealies, First and Second Session, Vienna, 26 March-24 May 1968 and 9 April-22 May 1969, Official Records, Documents of the Conference (UN. New York).

VERDROSS, Alfred Von (1937). 'Forbidden Treaties in Intemational Low." The American Jumal of Intemational Law. 31/4: 571 -577.

VERDROSS. Alfred (1966), "Jus Dispositivum and Jus Cogens In Intemetional Low?." The American bumal of International Law. 60/1: 55-63.

WEIL, Prosper (1983). "Towards Relative Normatuvity in International Low." The American Joumal of Intemational Law, 77: 413-442

YblLC (1966), Yearbook of the Intemational Law Commission, 1966, Vol. II. Documents of the Second Pant of the Seventeeth Session and of the Elgteenth Session Including the Reports of the Committee to the General Assembly (UN. New York). 